\title{
NO GLUE, NO STITCH TECHNIQUE OF CONJUNCTIVAL AUTOGRAFT IN PTERYGIUM SURGERY
}

\author{
P. Satyavani1, V. Padmavathi², Superna Mahendra ${ }^{3}$, Pratima $H^{4}$
}

${ }^{1}$ Assistant Professor, Department of Ophthalmology, Osmania Medical College.

${ }^{2}$ Assistant Professor, Department of Ophthalmology, Osmania Medical College.

${ }^{3}$ Civil Assistant Surgeon, Department of Ophthalmology, Osmania Medical College.

${ }^{4}$ Postgraduate, Department of Ophthalmology, Osmania Medical College.

ABSTRACT
BACKGROUND
The purpose of this study is to assess the efficacy and safety of "No glue, no stitch technique of conjunctival autograft after
pterygium excision" and also to study the recurrence rate for limbal conjunctival autograft after pterygium excision without sutures
or fibrin glue.

\section{MATERIALS AND METHODS}

The present study titled, "No glue, no stitch technique of conjunctival autograft in pterygium surgery" was a prospective interventional case series study conducted at Sarojini Devi Eye Hospital, Hyderabad, from December 2011 to May 2013. The study included fifty eyes of fifty consecutive patients who presented with primary pterygium to our outpatient department.

\section{RESULTS}

"No glue and no stitch technique of limbal conjunctival autografting" following pterygium excision is a safe, effective and economical option for the management of primary pterygium requiring surgical intervention. However, there is a risk of graft retraction, graft dislocation and recurrence in small percentage of cases. A prospective randomised controlled trial is required to investigate the long-term efficacy of this grafting technique in reducing recurrences.

\section{KEYWORDS}

Pterygium, Autograft, Glue, Fibrin, Limbal Cells, Mitomycin C.

HOW TO CITE THIS ARTICLE: Satyavani P, Padmavathi V, Mahendra S, et al. No glue, no stitch technique of conjunctival autograft in pterygium surgery. J. Evolution Med. Dent. Sci. 2016;5(78):5835-5842, DOI: 10.14260/jemds/2016/1316

\section{BACKGROUND}

Pterygium is a wing shaped conjunctival encroachment onto the cornea generally situated on the nasal side. It is more common in tropical areas with reported prevalence rates ranging from 0.3 to $29 \%$. Pterygium is more frequent in areas with more ultraviolet radiation in hot, dry, windy, dusty and smoky environments. 1,2

In general, conservative therapy for pterygium is warranted as recurrences after pterygia excision are frequent and aggressive.

Limbal conjunctival autograft is currently the most popular surgical procedure, as it has been suggested that including the limbal stem cells act as a barrier to the conjunctival cells migrating onto the corneal surface leading to low recurrence rate. ${ }^{3}$

The most common method of autograft fixation is suturing. Suture related complications include infection, granuloma formation and chronic inflammation. 4,5

We conducted this prospective interventional study in a series of patients to determine the outcome of sutureless gluefree limbal conjunctival autograft for primary pterygium surgery.

Financial or Other, Competing Interest: None.

Submission 02-08-2016, Peer Review 17-09-2016,

Acceptance 22-09-2016, Published 29-09-2016.

Corresponding Author:

Dr. Superna Mahendra

3-6-479, Fl. No. 301,

Sreeman Nirman Complex,

St. No. 6, Huriayatnagar, Hyderabad-500029.

E-mail: drsuperna95@gmail.com

DOI: $10.14260 /$ jemds $/ 2016 / 1316$

\section{History and Review of Literature}

The term pterygium is derived from the Greek word pterygion meaning "wing." Pterygium was first described by Susruta (India), the world's first surgeon ophthalmologist before 1000 A.D.6,7 Early work by Cameron et $\mathrm{al}^{8}$ indicated that pterygia occur more commonly where ultraviolet light intensity is highest.

Recurrence after a successful excision continues to remain a challenge in pterygium surgery. Ex-vivo expanded conjunctival epithelial sheet on an amniotic membrane substrate has been shown to achieve immediate epithelialisation of ocular surface reduced postoperative inflammation and faster ocular rehabilitation. The procedure is especially useful for closing large surgical defects following excision of extensive pterygium (Ang et al 2003). ${ }^{3}$

Kenyon et $\mathrm{al}^{9}$ first described a conjunctival autograft in 1985. They reported a recurrence rate of $5.3 \%$ and infrequent and relatively minor complications.

The limbal stem cells act as a barrier to the conjunctival cells migrating onto the corneal surface. Three authors (Kenyon, Koch and Guler) have specifically described the inclusion of limbal tissue in the graft and had low recurrence rates. ${ }^{9,10,11}$

The most common method of autograft fixation is suturing with drawbacks of prolonged operating time, postoperative discomfort, suture abscesses, button holes and granuloma formation which usually requires a second operation for removal (Starck et al 1991).12,13

Fibrin glue has been used as an alternative to sutures for securing the conjunctival grafts. Koranyi et al ${ }^{1}$ (2004) demonstrated a recurrence rate of $5.3 \%$ with glue versus $13.5 \%$ with sutures and suggested that immediate adherence 
of the graft and lack of postoperative inflammation may inhibit fibroblast ingrowth and reduce the recurrence.

The main issue in using commercial fibrin glue, despite viral inactivation techniques is transmission of infectious agents like Human Infection of parvovirus B19 (HPV B19) and prions (Foroutan et al 2011).14,15

The sutureless glue-free technique for pterygium surgery may prevent potential adverse reactions encountered with the use of foreign materials and in this small series provided safe and comparable results to current methods. (D de Wit et al 2010). The authors suggested that apposition of the lids to the bulbar conjunctiva provides a natural biological dressing and confers a unique wound healing environment. The lids provide compression, a smooth frictionless surface and a vascular bed with immune capability in close proximity to the injury site.

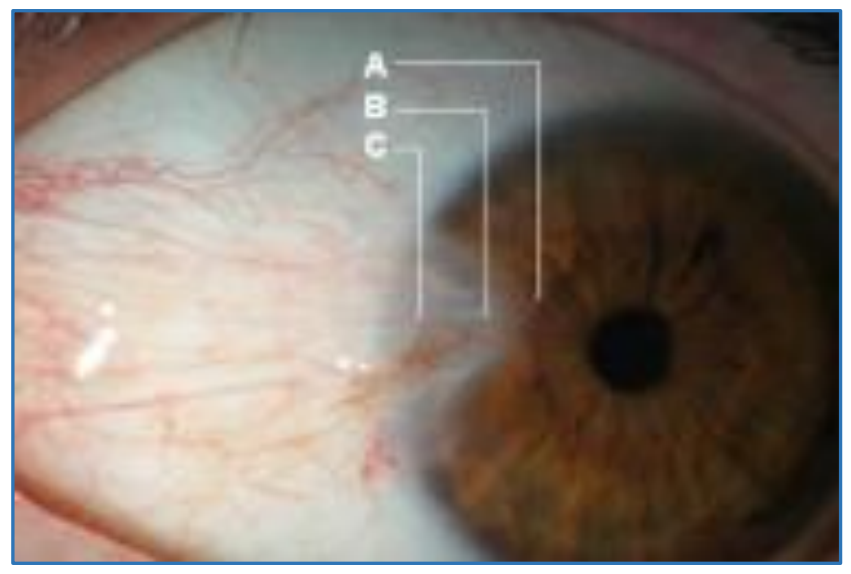

Macroscopic Anatomy of Pterygium

\section{A-Cap, B-Head, C-Body}

\section{MACROSCOPIC ANATOMY OF PTERYGIUM}

A pterygium consists of a head, a cap towards the advancing edge and the body lying limbal to the head.

\section{The Head}

It is the active part of the pterygium, which brings about changes in the cornea anterior to it forming the cap and activates the subconjunctival connective tissue behind it forming the body.

\section{The Body}

The body is the part limbal to the head, which assumes the characteristic wing shape. It lies mainly over the sclera.

\section{The Cap}

This is the apex of the pterygium anterior to the head. Unlike the head which is opaque, the cornea of the cap is viewable up to the Descemet's membrane.

\section{The Pigment Line}

This is seen about a millimetre ahead of the cap. It roughly follows the contour of the cap. This causes iron to be deposited at the advancing edge of the pterygium as the "Stocker's line."

\section{Microscopic Anatomy of the Pterygium}

Pterygium is characterised by proliferation, inflammatory infiltrates, fibrosis, angiogenesis and extracellular matrix breakdown.

\section{Pathogenesis}

The association between pterygium development and specific lifestyles, such as outdoors working or exposure to sunshine or dust led to the idea of chronic ocular surface irritation. It was also proposed that pterygium arises from other sunshinerelated conditions, such as the pingueculum, a hyalinised nodule appearing at the sclerocorneal limbus.

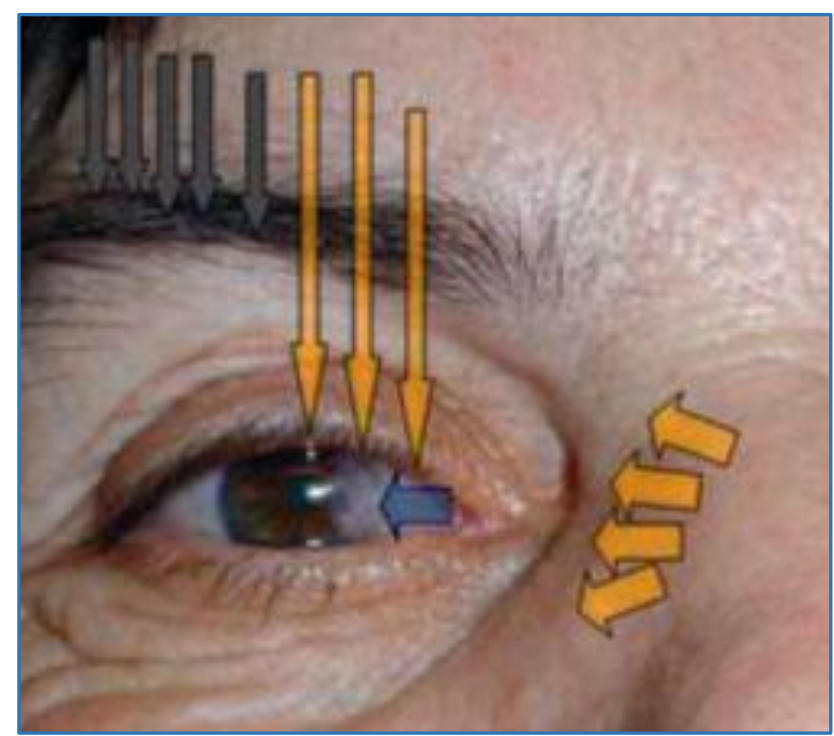

Role of UV Radiation

Light reflected from the lateral aspect of the nose on the corneal limbus as well as incident light falling on nasal limbus due to the short length of brow hair nasally (Yellow arrows) may contribute to the formation of pterygium nasally (Blue arrow). On the other hand, the temporal limbus is relatively protected from incident light due to the longer length of brow hair temporally.

\section{CLINICAL FEATURES \\ Symptoms}

Pterygium symptoms are highly variable, mainly depending on the severity. Irritation, itching, photophobia, tearing, pain and foreign body sensation, aesthetic appearance are the usual symptoms that are made worse by light, heat and windy conditions.

\section{The Following Changes in Vision may Occur}

- Glare and reduction of contrast sensitivity.

- True vision loss when growth over the cornea exceeds 2-3 mm

- Invasion of the pupil area when highly advanced ( $>4 \mathrm{~mm}$ of cornel invasion).

\section{Signs}

Pterygium is a triangular wing-like mass of fibrovascular tissue, extending from the conjunctiva, that encroaches a variable distance onto the cornea.

The lesion is usually on the horizontal meridian, particularly on the nasal side, although either nasal or temporal and double headed lesions can occur. 


\section{Classification of Pterygium}

\begin{tabular}{|c|l|}
\hline $\begin{array}{c}\text { Grade } \\
\text { I }\end{array}$ & $\begin{array}{l}\text { Atrophic-translucent, scantly vascularised, } \\
\text { episcleral vessels under the pterygium } \\
\text { are clearly distinguished }\end{array}$ \\
\hline $\begin{array}{c}\text { Grade } \\
\text { II }\end{array}$ & $\begin{array}{l}\text { Intermediate-episcleral vessels } \\
\text { are partially hidden }\end{array}$ \\
\hline $\begin{array}{c}\text { Grade } \\
\text { III }\end{array}$ & $\begin{array}{l}\text { Fleshy-thick, vascularised, episcleral } \\
\text { vessels are completely hidden }\end{array}$ \\
\hline \multicolumn{2}{|c|}{ According to their Morphology } \\
\hline Type I & $<2$ mm, low visual impact \\
\hline Type II & $\begin{array}{l}2-4 \text { mm, greater visual impact } \\
\text { by induced astigmatism }\end{array}$ \\
\hline Type III & $\begin{array}{l}>4 \text { mm, significant visual impact by } \\
\text { astigmatism and invasion of the optic zone }\end{array}$ \\
\hline \multicolumn{2}{|c|}{ According to Corneal Invasion } \\
\hline
\end{tabular}

Conservative therapy for pterygium is warranted unless one of the following circumstances arise:

1) Loss of visual acuity either because of induced astigmatism or encroachment onto the visual axis,

2) Marked cosmetic deformity,

3) Marked discomfort and irritation unrelieved with medical management,

4) Limitation of ocular motility secondary to restriction,

5) Documented progressive growth toward the visual axis, so that it is reasonable to assume that visual loss will ultimately occur.

\section{Medical Approaches}

General recommendations for the prevention of pterygium formation should include the avoidance of exposure to ultraviolet radiation.

In areas where exposure is high, the use of ultravioletabsorbing protective spectacles, sunglasses and hats is advisable.

- Mild irritative symptoms from pterygium may be managed with topical lubricants or a mild topical anti-histamine/vasoconstrictor.

- A mild topical corticosteroid or non-steroidal may be useful for moderate-to-severe vascular injection and irritative symptomatology.

- Secondary Dellen may be managed with preservative-free lubricating ointments and temporary patching for 24 hours.

\section{Surgical Approaches}

The fact that numerous different techniques exist for the surgical treatment of pterygium underscores the point that no single approach is universally successful.

\section{Pterygium Excision or Avulsion}

All procedures regardless of adjunctive measures employed, begin with the surgical removal of the pterygium from the globe.

\section{Bare Sclera Technique}

\section{Conjunctival Flaps and Conjunctival Autografts}

Various surgical strategies for the treatment of pterygium have been developed using the premise that close approximation of healthy conjunctival tissue at the denuded limbus after pterygium excision prevents recurrence. The three basic variations on this theme include excision with primary conjunctival closure, excision with conjunctival flap formation and conjunctival autografts.

\section{Primary Conjunctival Closure}

After pterygium is achieved by undermining adjacent normal superior and inferior bulbar conjunctiva and pulling the cut conjunctival edges together. Recurrence rates have varied from $2.1 \%$ to $88 \%$ this technique.

Rotational conjunctival flaps to cover the pterygium excisional site have been employed since 1940's.

Conjunctival autograft transplantation was described as a treatment for pterygium by Kenyon et $\mathrm{al}^{9}$ in 1985 . In this technique, a free conjunctival graft from the superotemporal bulbar conjunctiva is used to resurface the scleral surface after pterygium resection. A 5.3\% recurrence rate was reported from this study.

\section{THE VARIOUS METHODS TO SECURE THE CONJUNCTIVAL AUTOGRAFT ARE}

\section{Sutures}

10-0 Nylon or 8-0 Vicryl sutures can be used to secure the graft.

\section{Glue}

Recently, fibrin glue is being used to secure the graft over the dried up scleral bed.

\section{Electrocautery Pen}

\section{Suture-Free and Glue-Free Technique}

The latest method of securing the conjunctival autograft is the suture-free and glue-free technique.

\section{Limbal Conjunctival Autograft}

Limbal conjunctival autograft using stem cells is reported to be an effective adjuvant to lower the recurrence rate of pterygium as the limbal stem cells act as a barrier that prevent the growth of sub-conjunctival tissue onto the cornea.

\section{Amniotic Membrane}

An eye with recurrent pterygium that has undergone multiple surgeries usually lacks a great deal of normal non-scarred surrounding tissue and may have fornix shortening, symblepharon, and motility restriction.

\section{Lamellar Keratoplasty and Penetrating Keratoplasty}

If significant corneal thinning is present as a consequence of previous pterygium surgery, a lamellar keratoplasty may be indicated to restore the normal ocular surface integrity. In severe cases where the visual axis is affected by thinning and scarring, a penetrating keratoplasty may be indicated to visually rehabilitate the eye.

\section{ADJUVANT THERAPY \\ Radiotherapy}

Postoperative beta irradiation applied to the bare sclera is a relatively safe and effective adjuvant treatment for pterygium. Usually, it is applied as a single post-operative dose ( 2500 to 3500 rads), irradiation should be applied within 24 hours of pterygium excision or better still, on the surgical table for best results. 
Complications of radiotherapy include conjunctival inflammation, corneal opacities, scleritis, cataract, uveitis, corneal/scleral thinning, globe perforation and endophthalmitis.

\section{Chemotherapy}

Over the years, various chemotherapeutic agents have been used in the treatment of pterygium with the aim of preventing recurrence.

More recently, alcohol (Ethanol) and Anti-Vascular Endothelial Growth Factors (Anti-VEGF) have been introduced. Perhaps the most widely used adjuvant drugs are 5 fluorouracil (5FU) and Mitomycin C. Of the two, MMC has become more widely used and accepted.

\section{Complications of Pterygium Surgery}

Complications in pterygium surgery are generally related to the surgical technique and are relatively infrequent and not sight threatening.

\section{Intra-Operative Complications}

- Haemorrhage over the scleral bed.

- Inadvertent corneal perforation.

- Injury to the medial rectus muscle.

- Loss of orientation, flipping of the graft.

- Buttonholing of the graft.

\section{Post-Operative Complications}

The main post-operative complication is recurrence.

- Sub-conjunctival Haematomas.

- Conjunctival Autograft related.

- Graft Oedema.

- Graft Retraction.

- Graft Necrosis.

- Corneoscleral Dellen.

- Corneal Astigmatism.

- Epithelial inclusion Cyst's and Tenon's Granuloma.

- Sub-Conjunctival Fibrosis at Harvest Site causing Extraocular Muscle Restriction and Diplopia.

- Symblepharon formation more with Inferior Donor Site.

- Corneal Scarring.

\section{AIM AND OBJECTIVES OF THE STUDY \\ Aim of the Study}

To assess the efficacy and safety of "No glue, no stitch technique of conjunctival autograft after pterygium excision."

\section{OBJECTIVES}

- To study the recurrence rate for limbal conjunctival autograft after pterygium excision without sutures or fibrin glue.

- To study the post-operative complications for limbal conjunctival autograft after pterygium excision without sutures or fibrin glue.

- $\quad$ To compare the preoperative and postoperative visual acuity in the study group.

\section{MATERIALS AND METHODS}

The present study titled "No glue, no stitch technique of conjunctival autograft in pterygium surgery" was a prospective interventional case series study conducted at Sarojini Devi Eye Hospital, Hyderabad, between December 2011 and May 2013. The study included fifty eyes of fifty consecutive patients who presented with primary pterygium to our outpatient department.

\section{Inclusion Criteria}

Patients with primary pterygium for which surgery was recommended and those willing to participate in the study.

\section{Exclusion Criteria/Patients with}

- Pseudopterygium.

- Recurrent Pterygium.

- History of Ocular Trauma.

- History of Ocular Surface Infection.

Patients who were not willing to participate in the study were excluded.

A written informed consent was obtained from all the patients.

All Patients included in the Study Underwent the following Protocol

- Demographic data and a detailed history was obtained from them.

- Visual acuity testing using Snellen chart.

- $\quad$ Slit-lamp biomicroscopy for a detailed anterior segment evaluation and to note the location extent and grade of pterygium.

- Location of the pterygium - Nasal or temporal.

\begin{tabular}{|c|l|}
\hline Type I & \multicolumn{1}{|c|}{$<2 \mathrm{~mm}$, Low Visual Impact } \\
\hline Type II & $\begin{array}{l}\text { 2-4 mm, Greater Visual Impact by Induced } \\
\text { Astigmatism }\end{array}$ \\
\hline Type III & $\begin{array}{l}>4 \text { mm, Significant Visual Impact by } \\
\text { Astigmatism and Invasion of the Optic Zone }\end{array}$ \\
\hline \multicolumn{2}{|c|}{ Extent ofthe Pterygium } \\
\hline
\end{tabular}

\begin{tabular}{|c|l|}
\hline $\begin{array}{c}\text { Grade } \\
\text { I }\end{array}$ & $\begin{array}{l}\text { Atrophic: Translucent, Scantly Vascularised, } \\
\text { Episcleral Vessels under the Pterygium are } \\
\text { clearly Distinguished }\end{array}$ \\
\hline $\begin{array}{c}\text { Grade } \\
\text { II }\end{array}$ & $\begin{array}{l}\text { Intermediate-Episcleral Vessels are Partially } \\
\text { Hidden }\end{array}$ \\
\hline $\begin{array}{c}\text { Grade } \\
\text { III }\end{array}$ & $\begin{array}{l}\text { Fleshy-thick, Vascularised, Episcleral Vessels are } \\
\text { Completely Hidden }\end{array}$ \\
\hline \multicolumn{2}{|c|}{ According to their Morphology } \\
\hline
\end{tabular}

\section{Progressive or Non-Progressive}

All patients underwent IOP measurement and syringing prior to surgery.

The following investigations were done in each patient to rule out systemic disorders like diabetes, hypertension.

- $\quad$ RBS

- $\mathrm{BP}$

Xylocaine hypersensitivity test was done on all patients prior to the procedure. Ciprofloxacin $0.3 \%$ eye drops 6 th hourly were prescribed one day prior to the surgery.

\section{Surgical Procedure}

All patients in the present study underwent the "no glue, no stitch technique of conjunctival autograft" in the following manner.

- Peribulbar anaesthesia was given with $2 \%$ xylocaine and $0.5 \%$ bupivacaine.

- Under aseptic conditions, universal eye speculum was used to separate the lids and expose the surgical field. 
- The head was grasped with a fine-toothed forceps and the head was dissected off from the cornea with a crescent blade up to the limbus.

- The body of the pterygium was dissected and excised along with the tenon's fascia using Westcott's scissors. Where possible, haemostasis is allowed to occur spontaneously without the use of cautery.

- The excised head included a $1 \mathrm{~mm}$ border beyond the edges of the excised head at the limbus.

- The dissected area of the cornea was smoothened out by scraping with No. 15 Bard-Parker blade.

- The defect in the scleral bed is measured using Castroviejo's callipers.

- $\quad$ The globe was turned inferiorly and $2 \%$ lignocaine was injected sub-conjunctivally in the supero-temporal quadrant to form a bleb.

- Careful dissection between donor graft conjunctiva and Tenon's layer was done while fashioning the $1 \mathrm{~mm}$ oversized conjunctivo-limbal graft from the superotemporal conjunctiva.

- The exact limbal orientation of the graft was maintained while shifting the graft to the scleral bed.

- Injection gentamicin was given in the inferior bulbar conjunctiva and the eye was closed and padded for $24 \mathrm{hrs}$.

- Postoperatively, patients were started on the following drugs from the next day.

- Postoperatively, steroid drops were initially given four times a day and tapered over 6 weeks.

- Antibiotic drops were administered four times a day for 1-2 weeks.

- $\quad$ Lubricating eye drops four times a day for 4 weeks.

Patients were followed up postoperatively on first day, 1 month, 3 months and 6 months. Refraction was done at 3 months and BCVA was noted. The Snellen's visual acuity was converted into its Logmar equivalent and the visual acuity was compared pre- and post-operatively. Patients were evaluated for any recurrence or other post-operative complications like haemorrhage under the graft, graft oedema, graft retraction, graft dislocation, etc.

Recurrence was defined as the presence of fibrovascular tissue regrowth extending beyond the surgical limbus onto clear cornea.

\section{CASE 1}

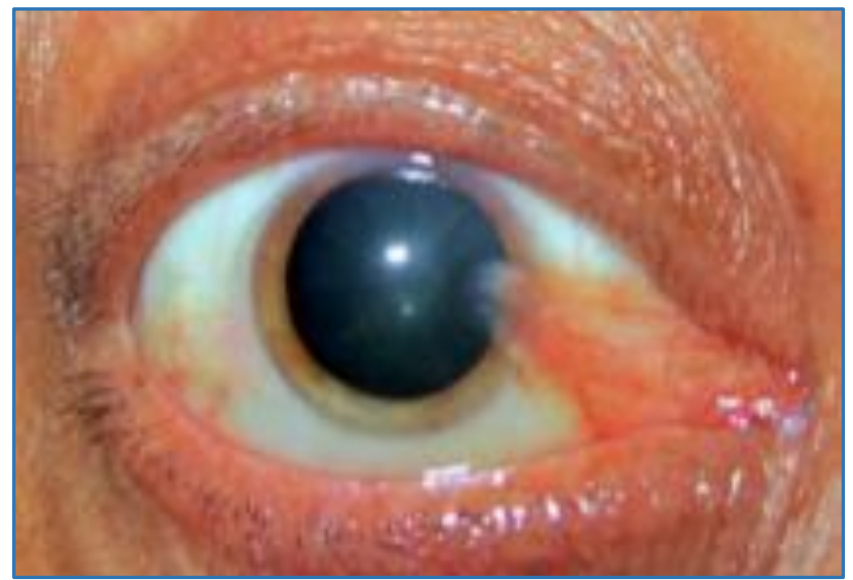

Pre-Operative

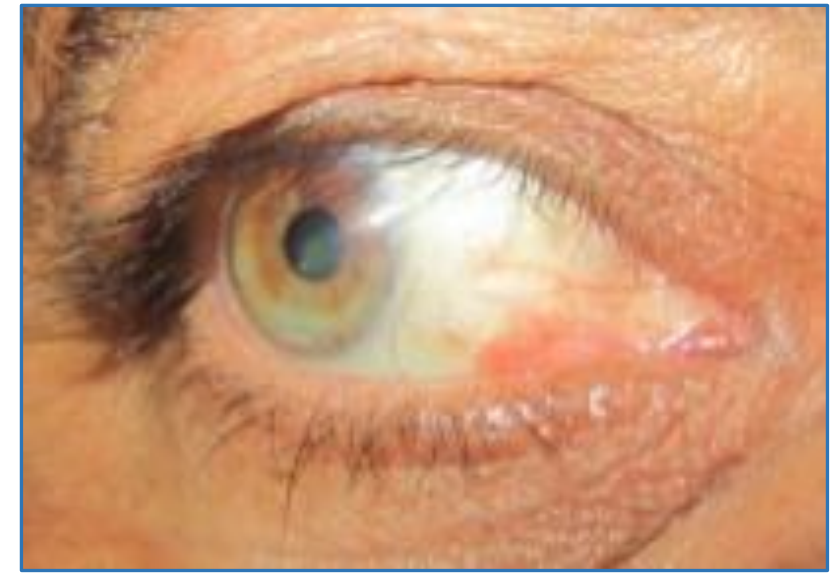

\section{Post-Operative}

\section{CASE 2}

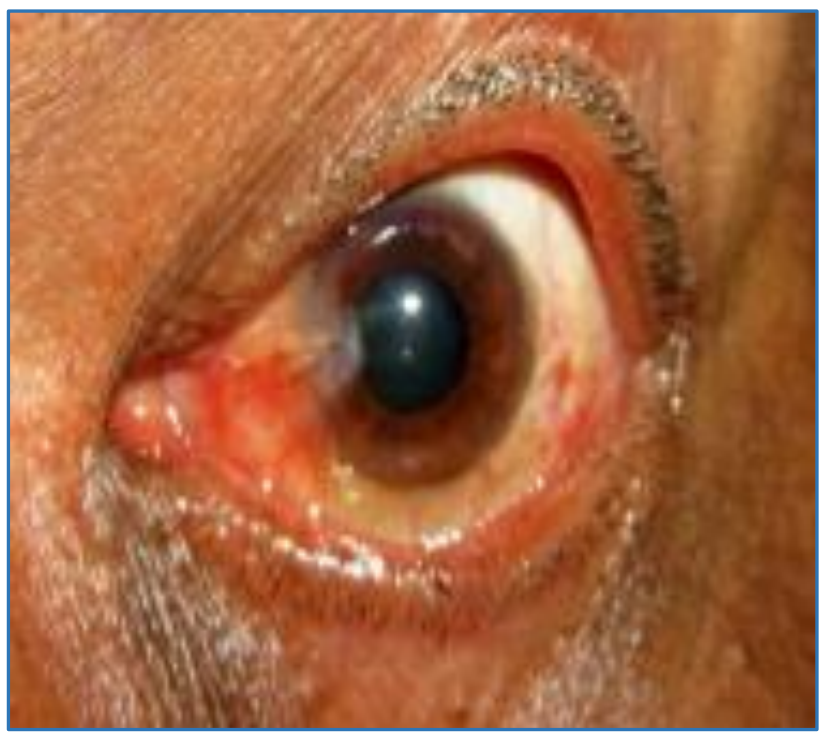

Pre-Operative

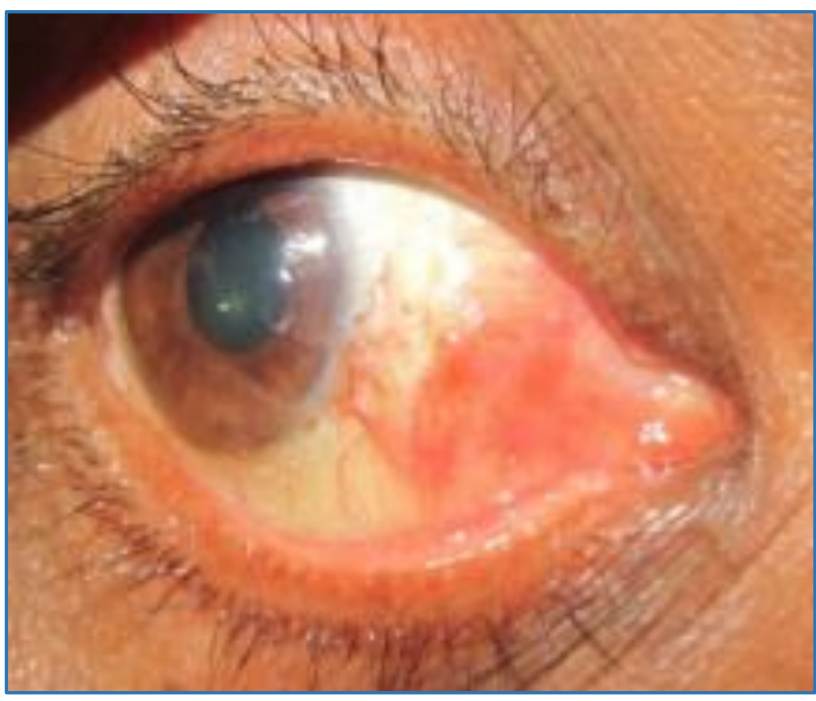

Post-Operative 


\section{RESULTS}

\section{Age Distribution}

Majority of the patients were between the ages of 30 to 50 years. No patients presented before 20 years of age. The average age of the study group was 47.6 years.

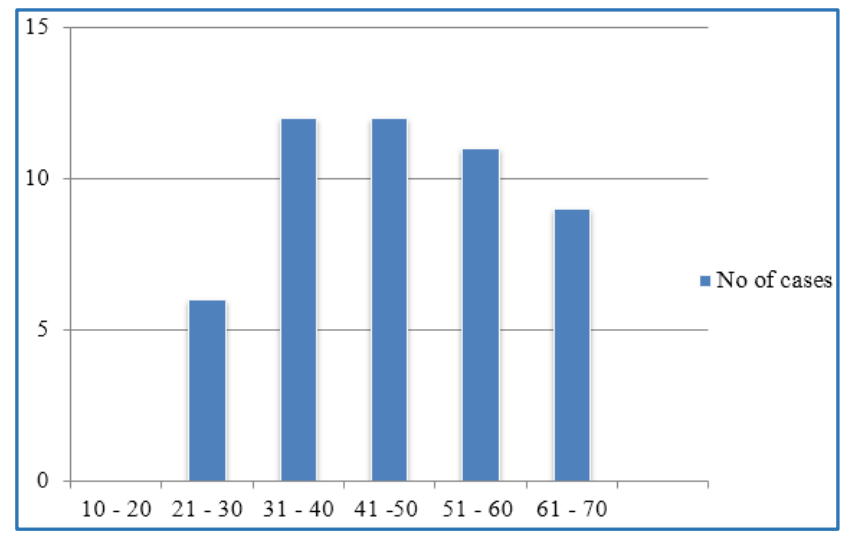

Graph 1: Age Distribution

\begin{tabular}{|c|c|c|}
\hline Age Range (Years) & No. of Patients & Percentage \\
\hline $10-20$ & 0 & 0 \\
\hline $21-30$ & 6 & 12 \\
\hline $31-40$ & 12 & 24 \\
\hline $41-50$ & 12 & 24 \\
\hline $51-60$ & 11 & 22 \\
\hline $61-70$ & 9 & 18 \\
\hline Total Table 1: Age Distribution \\
\hline \multicolumn{2}{|c|}{} \\
\hline \multicolumn{2}{|c|}{} \\
\hline
\end{tabular}

\section{Sex Incidence}

Of the 50 patients included in the study, 21 were males (42\%) and 29 were females (58\%).

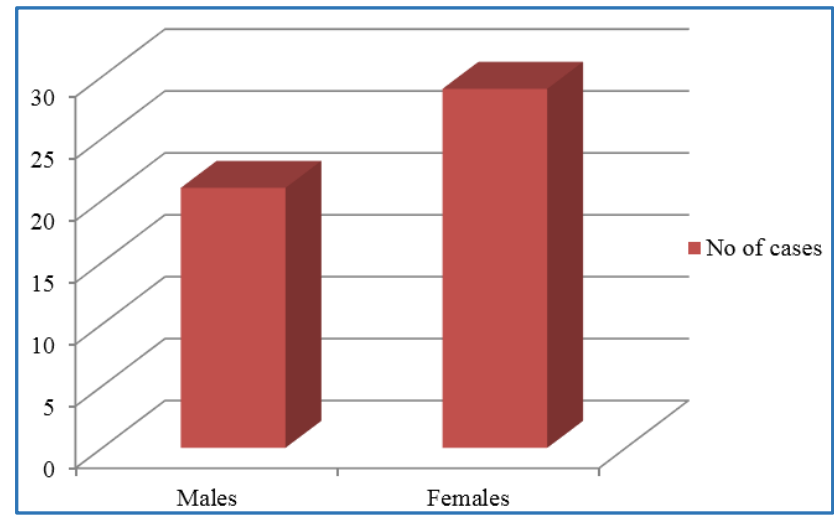

Graph 2: Sex Incidence

\begin{tabular}{|c|c|c|}
\hline Sex & No. of Patients & Percentage \\
\hline Male & 21 & 42 \\
\hline Female & 29 & 58 \\
\hline Total & $\mathbf{5 0}$ & $\mathbf{1 0 0}$ \\
\hline \multicolumn{2}{|c|}{ Table 2: Sex Incidence } \\
\hline
\end{tabular}

\section{Presenting Complaints}

The most frequent complaint at the initial presentation was noticing a fleshy growth in the eye in all the cases $(100 \%)$. The other common complaint was diminished vision in $50 \%$ of the cases. The other complaints include redness in $24 \%$, pain in
$30 \%$, watering in $16 \%$ and photophobia in $34 \%$ of the cases. Out of 50 patients in the study, $60 \%$ had a history of use of topical medications for the same complaints.

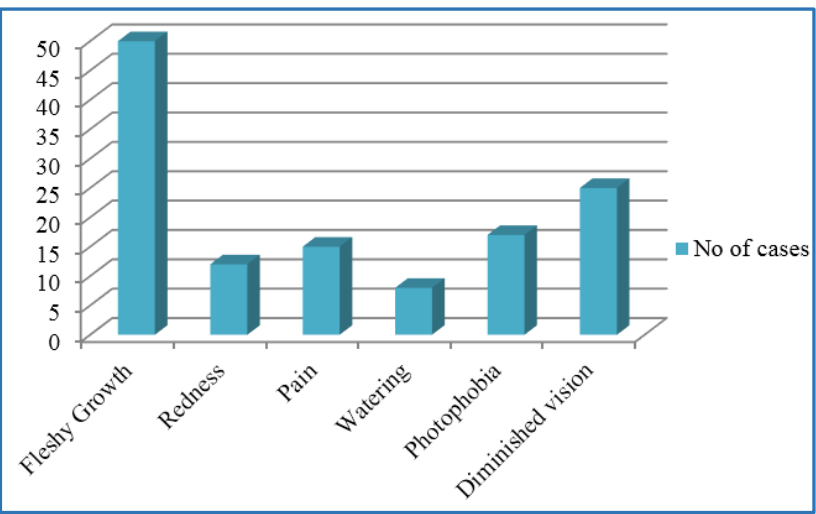

Graph 3: Presenting Complaints

\begin{tabular}{|c|c|c|}
\hline Presenting Complaints & No. of Patients & Percentage \\
\hline Fleshy Growth & 50 & 100 \\
\hline Redness & 12 & 24 \\
\hline Pain & 15 & 30 \\
\hline Watering & 8 & 16 \\
\hline Photophobia & 17 & 34 \\
\hline Diminished Vision & 25 & 50 \\
\hline \multicolumn{2}{|c|}{ Table 3: Presenting Complaints } \\
\hline
\end{tabular}

\section{Pterygium Location}

The location of pterygium was nasal in 47 eyes (94\%) and temporal in 3 eyes (6\%).

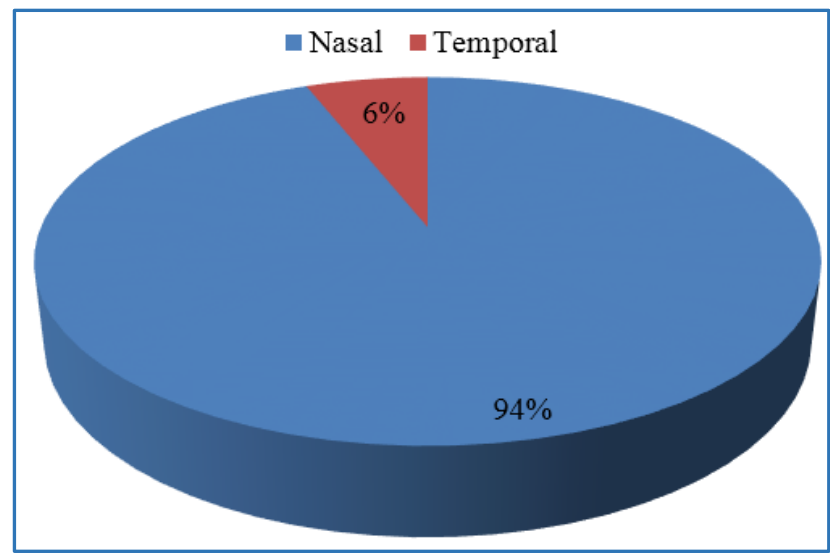

Graph 4: Pterygium Location

\begin{tabular}{|c|c|c|}
\hline Pterygium Location & No. of Eyes & Percentage \\
\hline Nasal & 47 & 94 \\
\hline Temporal & 3 & 6 \\
\hline Total & $\mathbf{5 0}$ & $\mathbf{1 0 0}$ \\
\hline \multicolumn{2}{|c|}{ Table 4: Pterygium Location } \\
\hline
\end{tabular}

\section{Characteristics of Pterygium}

Majority of the patients presented with type III (50\%) and grade III (64\%); $12 \%$ of the patients presented with type I and $38 \%$ of the patients presented with type II pterygium; $36 \%$ of the patients presented with grade II pterygium. 


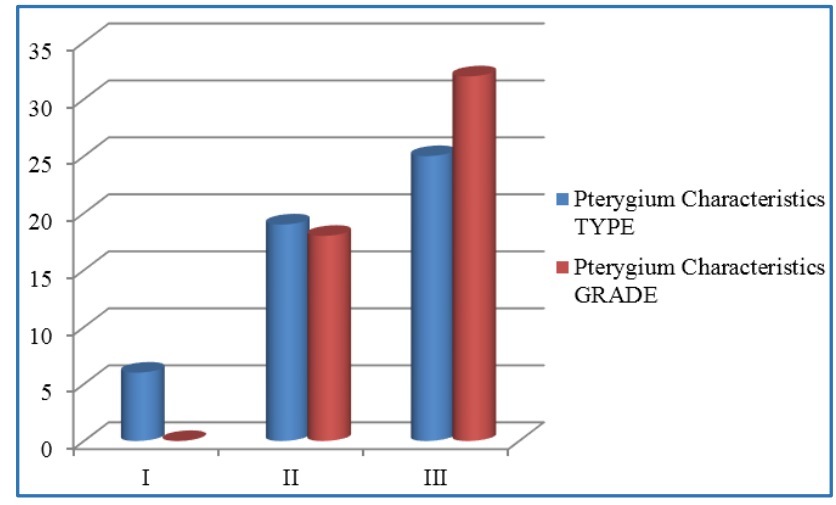

Graph 5: Characteristics of Pterygium

\begin{tabular}{|c|c|c|c|}
\hline $\begin{array}{c}\text { Pterygium } \\
\text { Characteristics }\end{array}$ & I & II & III \\
\hline Type & $6(12 \%)$ & $19(38 \%)$ & $25(50 \%)$ \\
\hline Grade & 0 & $18(36 \%)$ & $32(64 \%)$ \\
\hline \multicolumn{4}{|l}{ Table 5: Characteristics of Pterygium } \\
\hline
\end{tabular}

\section{Visual Acuity}

16 patients out of 50 patients $(32 \%)$ included in the study showed an improvement in visual acuity postoperatively. In 34 patients $(68 \%)$ visual acuity remained the same. The mean visual acuity preoperatively was $0.54 \pm 0.4 \mathrm{D}$, which improved to $0.62 \pm 0.36(\mathrm{P}=0.002)$ post-operatively.

\begin{tabular}{|c|c|c|c|}
\hline & $\begin{array}{c}\text { Pre-Operative } \\
\text { Mean VA } \pm \text { SD }\end{array}$ & $\begin{array}{c}\text { Post-Operative } \\
\text { Mean VA } \pm \text { SD }\end{array}$ & $\begin{array}{c}\text { P } \\
\text { Value }\end{array}$ \\
\hline BCVA & $0.54 \pm 0.4 \mathrm{D}$ & $0.62 \pm 0.36$ & 0.002 \\
\hline \multicolumn{4}{|c|}{$\begin{array}{c}\text { Table 6: Pre-Operative and Post-Operative } \\
\text { Visual Acuity after Pterygium Surgery }\end{array}$} \\
\hline
\end{tabular}

\section{Recurrences}

Out of the 50 patients, 4 patients showed recurrence. Of the 4 patients, 3 patients showed recurrence in the $3^{\text {rd }}$ month and the other patient showed recurrence in $6^{\text {th }}$ month of followup.

\begin{tabular}{|c|c|c|}
\hline Recurrence & No. of Cases & Percentage \\
\hline Present & 4 & 8 \\
\hline Absent & 46 & 92 \\
\hline Total & 50 & 100 \\
\hline Table 7: Recurrence after Pterygium Surgery \\
\hline
\end{tabular}

\section{DISCUSSION}

This prospective interventional case series study was conducted at Sarojini Devi Eye Hospital, Hyderabad, between Dec 2011 and May 2013.

50 eyes of 50 patients were included in the study. All the patients had a followup for a minimum period of 6 months.

Among the 50 patients included in the study, 21 were males (42\%) and 29 were females (58\%). Majority of the patients were between the ages of 30 and 50 years. The mean age of the study group was 47.6 years.

Majority (74\%) of the patients included in the study were engaged in outdoor occupations, which could be a predisposing factor for the development of pterygium.

All the patients included in the study had primary pterygia. The location of pterygium was nasal in 47 eyes (94\%) and temporal in 3 eyes $(6 \%)$.

Majority of the patients presented with type III (50\%) and grade III (64\%); $12 \%$ of the patients presented with type I and
$38 \%$ of the patients presented with type II pterygium; $36 \%$ of the patients presented with grade II pterygium.

16 patients out of 50 patients (32\%) included in the study showed an improvement in visual acuity post-operatively. In 34 patients $(68 \%)$ visual acuity remained the same. The mean visual acuity preoperatively was $0.54 \pm 0.4 \mathrm{D}$, which improved to $0.62 \pm 0.36(\mathrm{P}=0.002)$ post-operatively.

The mean surgical time was 13.5 minutes in our study.

No significant intraoperative complications were noted in this study.

Graft retraction was seen in 3 eyes (6\%) in our series, which disappeared once the chemosis was controlled. It did not affect the final position of the graft. Graft retraction occurred in $20 \%$ cases. Tan advocated that risk of graft retraction could be minimised with meticulous dissection of subepithelial graft tissue.

In our series, we had a recurrence rate of $8 \%$ with a followup of 6 months. The lids provide compression, a smooth frictionless surface and a vascular bed with immune capability in close proximity to the injury site. Foroutan et al (2011) ${ }^{14}$ had a recurrence rate of $13.33 \%$ ( 2 eyes out of 15 ) in three year followup with autologous fibrin.

The preference for the site of donor graft in our series was superior, as this area gets covered by the upper lid enabling better cosmoses and healing.

It was a non-randomised case series study and consisted of a small study population and a relatively short follow-up period of 6 months.

\section{CONCLUSION}

"No glue and no stitch technique of limbal conjunctival autografting" following pterygium excision is a safe, effective and economical option for the management of primary pterygium requiring surgical intervention. However, there is a risk of graft retraction, graft dislocation and recurrence in small percentage of cases. A prospective, randomised, controlled trial is required to investigate the long-term efficacy of this grafting technique in reducing recurrences.

\section{REFERENCES}

1. G Koranyi, Seregard S, Kopp ED. Cut and paste: a no suture, small incision approach to pterygium surgery. Br J Ophthalmol 2004;88(7):911-4.

2. Ang LP, Chua JL, Tan DT. Current concepts and techniques in pterygium treatment. Curr Opin Ophthalmol 2007;18(4):308-13.

3. Malik KP, Goel R, Gupta A, et al. Efficacy of sutureless and glue free limbal conjunctival autograft for primary pterygium surgery. Nepal J Ophthalmol 2012;4(2):230-5.

4. Allan BD, Short P, Crawford GJ, et al. Pterygium excision with conjunctival autografting: an effective and safe technique. Br J Ophthalmol 1993;77(11):698-701.

5. Tan D. Conjunctival grafting for ocular surface disease. Curr Opin Ophthalmol 1999;10(4):277-81.

6. Rosenthal JW. Chronology of pterygium therapy. Am J Ophthal 1953;36(11):1601-16.

7. Singh G. Pterygium and its surgery. In: Foster CS, Azar DT, Dohlman CH. eds. The Cornea. Vol 4. Philadelphia: Lippincott Williams \& Wilkins 2005:999-1017.

8. Cameron ME. Pterygium throughout the World. Springfield Ill: Charles C Thomas 1965. 
9. Kenyon KR, Wagoner MD, Hettinger ME. Conjunctival autograft transplantation for advanced and recurrent pterygium. Ophthalmology 1985;92(11):1461-70.

10. Koch JM, Mellin JB, Waubke TN. The pterygium, autologous conjunctiva-limbus transplantation as treatment. Ophthalmology 1992;89(2):143-6.

11. Guler M, Sobaci G, Liker S, et al. Limbal-conjunctival autograft transplantation in cases with recurrent pterygium. Acta Ophthalmol (Copenh)1994;72(6): 721-6.

12. Dushku N, Reid TW. Immunohistochemical evidence that human pterygia originate from an invasion of vimentinexpressing altered limbal epithelial basal cells. Curr Eye Res 1994;13(7):473-81.
13. Starck T, Kenyon KR, Serrano F. Conjunctival autograft for primary and recurrent pterygia: surgical technique and problem management. Cornea 1991;10(3):196-202.

14. Foroutan A, Beigzadeh F, Ghaempanah MJ, et al. Efficacy of autologous fibrin glue for primary pterygium surgery with conjunctival autograft. Iranian Journal of Ophthalmology 2011;23(1):39-47.

15. Oswald AM, Joly LM, Gury C, et al. Fatal intraoperative anaphylaxis related to aprotinin after local application of fibrin glue. Anesthesiology 2003;99(3):762-3. 